\title{
ACTIVITY OF SUPEROXIDE DISMUTASE MIMIC OF [Mn(SALEN)OAC] COMPLEX COMPOUND NON-ENZYMATICALLY IN VITRO THROUGH RIBOFLAVIN PHOTOREDUCTION
}

\section{AKTIVITAS MIMIK SUPEROKSIDA DISMUTASE SENYAWA KOMPLEKS [Mn(SALEN)OAc] SECARA IN VITRO NON-ENZIMATIK MELALUI FOTOREDUKSI RIBOFLAVIN}

\author{
Yusi Deawati*1, Djulia Onggo ${ }^{1}$, Irma Mulyani ${ }^{1}$, Iwan Hastiawan ${ }^{2}$, Dikdik Kurnia ${ }^{3}$ \\ ${ }^{1}$ Inorganic and Physical Chemistry Research Group, Faculty of Mathematics and Natural Sciences, \\ Institut Teknologi Bandung, Bandung, Indonesia \\ ${ }^{2}$ Physical and Inorganic Chemistry Laboratory, Department of Chemistry, Faculty of Mathematics \\ and Natural Sciences, Universitas Padjadjaran, Sumedang, Indonesia \\ ${ }^{3}$ Organic Chemistry Laboratory, Department of Chemistry, Faculty of Mathematics and Natural \\ Sciences, Universitas Padjadjaran, Sumedang, Indonesia \\ *email.yusi_dea@yahoo.com, yusi.deawati@unpad.ac.id
}

Received December 26, 2016; Accepted May 8, 2017; Available online May 30, 2017

\begin{abstract}
The complex compound of [Mn(salen)OAc] can serve as mSOD and its activity has been determined nonenzymatically in vitro through riboflavin photoreduction. The complex was synthesized from $\mathrm{Mn}(\mathrm{OAc})_{2} .4 \mathrm{H}_{2} \mathrm{O}$ and $\mathrm{H}_{2}$ salen. Based on the elemental analysis, the $\mathrm{C}=56.69 \% ; \mathrm{H}=4.21 \%$; and $\mathrm{N}=7.52 \%$ content are corresponding to the chemical formula of $\mathrm{MnC}_{18} \mathrm{H}_{17} \mathrm{~N}_{2} \mathrm{O}_{4}$. The functional groups and ionic species in the complex have been analyzed by infrared spectroscopy and ESI-MS. SOD activity was determined by mixing complex at various concentrations with riboflavin and nitroblue tetrazolium (NBT), then the mixture was lighted with 20 watts tungsten lamp for 15 minutes in a closed box. Then the reduced NBT absorptions were measured at $\lambda 560 \mathrm{~nm}$. The difference of absorbance between standard and sample solutions (without and with riboflavin, respectively) was multiplied by $100 \%$ to obtain \%inhibition of each various sample concentration against NBT. SOD activity was obtained from $\mathrm{IC}_{50}$ data defined as a $50 \%$ inhibition of the plot curve of $\%$ inhibition to the concentration of the complex. The result obtained for this compound is $\mathrm{IC}_{50}=2.7 \pm 0.1 \mu \mathrm{M}$ as well as enzymatic method. Therefore, this method can be used to determine the SOD activity by giving more stability and accuracy of $\mathrm{IC}_{50}$ value.
\end{abstract}

Keywords: [Mn(salen)OAc], SOD, non-enzymatic, photoreduction, riboflavin

\begin{abstract}
ABSTRAK
Senyawa kompleks [Mn(salen)OAc] dapat berfungsi sebagai mSOD dan aktivitasnya telah ditentukan secara in vitro non-enzimatik melalui fotoreduksi riboflavin. Kompleks ini disintesis dari $\mathrm{Mn}(\mathrm{OAc})_{2} .4 \mathrm{H}_{2} \mathrm{O}$ dan $\mathrm{H}_{2}$ salen. Berdasarkan analisis unsur diperoleh kadar unsur $\mathrm{C}=56,69 \% ; \mathrm{H}=4,21 \%$; dan $\mathrm{N}=7,52 \%$ yang sesuai dengan rumus kimia $\mathrm{MnC}_{18} \mathrm{H}_{17} \mathrm{~N}_{2} \mathrm{O}_{4}$. Gugus fungsi dan spesi ion dalam kompleks tersebut telah dianalisis dengan spektroskopi inframerah dan ESI-MS. Aktivitas SOD ditentukan dengan mencampurkan kompleks pada berbagai konsentrasi dengan riboflavin dan nitroblutetrazolium (NBT), yang kemudian campuran tersebut disinari oleh lampu wolfram 20 watt selama 15 menit pada kotak tertutup. Setelah itu serapan NBT tereduksi diukur pada $\lambda 560 \mathrm{~nm}$. Perbedaan absorbansi antara larutan standar dan sampel (masing-masing tanpa dan dengan adanya riboflavin) dikalikan dengan $100 \%$ untuk mendapatkan $\%$ inhibisi dari setiap variasi konsentrasi sampel terhadap NBT. Aktivitas SOD diperoleh dari data $\mathrm{IC}_{50}$ yang ditentukan sebagai $50 \%$ inhibisi pada kurva aluran persen inhibisi terhadap konsentrasi kompleks. Hasil yang diperoleh untuk kompleks ini adalah $\mathrm{IC}_{50}=2,7 \pm 0,1 \mu \mathrm{M}$ sama seperti pada metode enzimatik. Oleh karena itu metode ini dapat digunakan untuk menentukan aktivitas SOD dengan memberikan nilai $\mathrm{IC}_{50}$ yang lebih stabil dan akurat.
\end{abstract}

Kata kunci: [Mn(salen)OAc], SOD, non-enzimatik, fotoreduksi, riboflavin

\section{INTRODUCTION}

Superoxide radical $\left(\mathrm{O}_{2}{ }^{-}\right)$is one of the reactive oxygen species (ROS) which the most dangerous in comparison with other
ROS (Vecchio \& Lanza, 2009). The existence of excessive radicals in the body can cause tissue damage associated with the emergence of various diseases, such as rheumatoid 
arthritis, cancer, neurodegenerative disorders, complications of diabetes, stroke, inflammation and reperfusion injury.

Superoxide reactivity could be overcome by a metalloenzyme known as superoxide dismutase (SOD), that catalyze the dismutation of $\mathrm{O}_{2}{ }^{-}$reactive species to $\mathrm{O}_{2}$ and $\mathrm{H}_{2} \mathrm{O}_{2}$ (Vecchio \& Lanza, 2009). But the limited number of metalloenzyme in the body, the use of supplements containing SOD from plants extract or other living beings or synthetic SOD become an alternative. Synthetic SOD is known as SOD mimic or mSOD (Miriyala et al., 2012).

Manganese (III)-salen complexes compound are one of an mSOD type which the activities much-studied. The complex compounds have high stability and relatively low toxicity (Haberle, Reboucas, \& Spasojevic, 2010). Several compounds of $\mathrm{Mn}(\mathrm{III})$-salen, with variety salen ligand structure, generally have monomeric structures (Doctrow et al., 2002; Meftah \& Yazdanparast, 2013).

The in vitro indirect SOD test is an initial test conducted to determine a potential of a complex compound as an mSOD (Iranzo, 2011). The test principle is competition between $\mathrm{mSOD}$ and active redox indicator to react with $\mathrm{O}_{2}{ }^{-}$species. The activity of an mSOD of a complex compound shown by the ability of the complex compound to inhibit reduction process of the active redox indicator by $\mathrm{O}_{2}{ }^{-}$species. Through this indirect SOD test, SOD activity is obtained as $\mathrm{IC}_{50}$ value, that is a quantity used to express one unit of SOD activity. $\mathrm{IC}_{50}$ is a quantity that describes the amount of SOD to inhibit the reduction reaction of an active redox indicators by species $\mathrm{O}_{2}{ }^{--}$as much as $50 \%$.

Based on the source of $\mathrm{O}_{2}{ }^{--}$species, there are two types of SOD assay, that is enzymatic and non-enzymatic methods. In the enzymatic method (McCF: McCordFridovich), xanthine and xanthine oxidase are used as $\mathrm{O}_{2}{ }^{-}$species source, while in the nonenzymatic method, $\mathrm{O}_{2}{ }^{--}$species sources which often used are derived from flavin photoreduction (Kostyuk, Potapovich, Kostyuk, \& Cherian, 2007; Retnoningrum et al., 2016), organic compound autooxidation (Li, 2012) and gamma irradiation (Barnese, Gralla, Cabelli, \& Valentine, 2008). The nonenzymatic method through riboflavin photoreduction is currently used because it is easier to use, relatively cheaper, and accurate.
The complex compound of [Mn(salen)OAc] is one of manganese(III)salen which is a pioneer as mSOD. The patent name of the compound is EUK-108, provided by a pharmaceutical company in the United States (Eukarion, Inc.) (Doctrow et al., 2002). There are two studies that reported $\mathrm{IC}_{50}$ values of [Mn(salen)OAc] complex compound tested with $\mathrm{McCF}$ (indicator: cyt c) enzymatic method, those are $0.7 \pm 0.2 \mu \mathrm{M}$ (Doctrow et al., 2002) and $2.54 \pm 0.2 \mu \mathrm{M}$ (Vecchio \& Lanza, 2009). Both the $\mathrm{IC}_{50}$ values differ greatly, which indicate that the SOD test by the McCF enzymatic method gives inconsistency $\mathrm{IC}_{50}$ values of a compound. This may be caused by enzyme activity decreased or unstable.

The non-enzymatic method through riboflavin photoreduction (indicator: NBT)/rb-NBT has been widely used to determine SOD activity of various types of natural SOD, such as SOD-manganese recombinant hybrid of Staphylococcus equorum and $S$. saprophyticus with Escherichia coli (Retnoningrum et al., 2016) and SOD-manganese from Staphylococcus equorum (Indrayati, Asyarie, Suciati, \& Retnoningrum, 2014). However, there were only found 9 SOD mimics of manganese complex compound whose activities were determined by this rb-NBT non enzymatic method, those are: 1 complex of manganese(II)-bovine serum albumin (Yan et al., 2016), 2 complexes of manganese(III)salen derivatives: $\mathrm{Na}\left[\mathrm{Mn}{ }^{\mathrm{III}}\left(5-\mathrm{SO}_{3}\right.\right.$ salpnOH $\left.)\left(\mathrm{H}_{2} \mathrm{O}\right)\right] .5 \mathrm{H}_{2} \mathrm{O}$ dan $\mathrm{Na}\left[\mathrm{Mn}^{\mathrm{III}}\left(5-\mathrm{SO}_{3}-\right.\right.$ salpn)(MeOH)].4 $\mathrm{H}_{2} \mathrm{O}$ (Moreno, Daier, Palopoli, Tuchagues, \& Signorella, 2010), 2 complexes of manganese (IV)-salen derivatives: $\left[\mathrm{Mn}^{\mathrm{IV}}(\right.$ salbutO $\left.) \mathrm{N}_{3}\right]$ and $\left[\mathrm{Mn}^{\mathrm{IV}}\right.$ (salbutO)SCN] (Daier, Moreno, Duhayon, Tuchagues, \& Signorella, 2010), 1 complex of manganese(II)-bacitracin (Piacham et al., 2006), 2 complexes of manganese (II)-macrocyclic: $\quad\left[\mathrm{Mn}^{\mathrm{II}}(1-\right.$ (benzimidazol-2-ylmethyl)-1,4,7triazacyclononane $\left.) \mathrm{Cl}_{2}\right]$ and $\left[\mathrm{Mn}^{\mathrm{II}}(1,4-\right.$ bis(benzimidazol-2-ylmethyl)-1,4,7-

triazacyclonone) $\mathrm{Cl}] \mathrm{ClO}_{4} \cdot \mathrm{MeOH}$, and 1 complex of manganese(III)-multidentate acyclic $\left[\mathrm{Mn}^{\mathrm{III}}(\mathrm{bpb})\left(\mathrm{H}_{2} \mathrm{O}\right) \mathrm{Cl}\right]$ (Iranzo, 2011).

New in this research, the nonenzymatic method through riboflavin photoreduction using NBT indicator was used to determine SOD activity $\left(\mathrm{IC}_{50}\right)$ of the 
[Mn(salen)OAc]. The purpose of this study is to evaluate the ability of this rb-NBT nonenzymatically method in analyzing SOD activity of the $[\mathrm{Mn}(\mathrm{salen}) \mathrm{OAc})]$ complex compound.

\section{EXPERIMENTAL SECTION}

In this research, the $[\mathrm{Mn}($ salen $) \mathrm{OAc}]$ complex has been synthesized, characterized, and SOD activity tested by the in vitro nonenzymatic method through riboflavin photoreduction using NBT indicator (rb-NBT)

\section{Materials}

In this study, chemicals that used are the high purity grade from Sigma-Aldrich, those are ethylenediamine 99\%, salicylaldehyde $98 \%$, absolute ethanol $99.5 \%$, manganese(II) acetate tetrahydrate $99 \%$, distilled water, and methanol $99.8 \%$. The chemicals used in the SOD test are nitroblue tetrazolium chloride (NBT) $98 \%$ from Thermoscientific, tetramethylethylenediamine (TEMED) 99\% from Biorad, riboflavin 98\%, the solution of $1.0 \mathrm{M}$ phosphate buffer $\mathrm{pH}$ $7.4\left(25^{\circ} \mathrm{C}\right)$, and aqua bidest.

\section{Instrumentation}

Tools and instruments used in this study include glasswares, Perkin-Elmer 240 elemental analyzer, FTIR Nicolet Magna IR 750 series II spectrophotometer, ESI-MS Bruker Daltonics esquire3000 plus spectrometer, Sherwood Scientific magnetic susceptibility balance (MSB), and HANNA Instruments HI 8819W Professional ATC conductometer. While, equipment used in the SOD activity test include micropipette 1000 and 30-300 $\mu \mathrm{L}, 96$-well microplate, light box $\left(25 \times 25 \times 25 \mathrm{~cm}^{3}\right)$ coated by aluminum foil and using a 20 watts tungsten lamp, and Multiskan Go Thermofisher Scientific UV/vis double beam microplate reader spectrophotometer.

\section{Procedures \\ Synthesis of [Mn(salen)OAc] Complex}

The $[\mathrm{Mn}$ (salen)OAc] complex was prepared using a published procedure (Boucher \& Farrell, 1973) with using glass beakers instead of reflux and methanol as a solvent for recrystallization instead of petroleum. The $\mathrm{H}_{2}$ salen $(\mathrm{N}, \mathrm{N}$ 'bis(salicylidene)ethane-1,2-diamine) that used as a ligand was prepared from salicylaldehyde and ethylenediamine by the reported method
(Haikarainen, Sibila, Pietikainen, Pajunen, \& Mutikainen, 2001). The dark brown crystals of the $[\mathrm{Mn}(\mathrm{salen}) \mathrm{OAc}]$ complex were obtained in $45-67 \%$ yield.

\section{SOD Assay: Riboflavin Photoreducion Test of [Mn(salen)OAc] Complex}

The $[\mathrm{Mn}($ salen$) \mathrm{OAc}]$ complex was tested for SOD activity using a previously described method (Kostyuk et al., 2007). The SOD activity measurement of the complex compound was based on the reduction of nitroblue tetrazolium by superoxide anions generated in riboflavin photoreduction, which was carried out at room temperature $\left(25^{\circ} \mathrm{C}\right)$ under fluorescent lighting $(20 \mathrm{w}, 20 \mathrm{~cm})$. The sample solution was prepared in 12 variations of concentration and each $40 \mu \mathrm{L}$ of them was added to a solution $(200 \mu \mathrm{L})$ containing $6 \mu \mathrm{M}$ of riboflavin, $0.8 \mathrm{mM}$ of $\mathrm{N}, \mathrm{N}, \mathrm{N}^{\prime}, \mathrm{N}^{\prime}-$ tetramethylethylenediamine (TEMED) in 16 $\mathrm{mM}$ phosphate buffer ( $\mathrm{pH} 7.4$ ), and $85 \mu \mathrm{M}$ of nitroblue tetrazolium (NBT) in a microplate. The sample mixtures were subjected to light exposure as mentioned above for $15 \mathrm{~min}$ and the colorimetric activity assay by a microplate reader spectrophotometer follows the generation of NBT-diformazan, which absorbs at $560 \mathrm{~nm}$ (Janknegt, Rijstenbil, van de Poll, Gechev, \& Buma, 2007).

The absorbance of sample blank mixture (blank 1), without riboflavin, was measured as well. In the standard mixture and its blank (blank 2), methanol solvent was added instead of the sample solution. The difference of absorbance between standard and samples (without and with riboflavin, respectively) was multiplied by $100 \%$ to obtain \% inhibition of each various sample concentration against NBT (Retnoningrum et al., 2016).

\section{RESULTS AND DISCUSSION}

\section{Characterization of $\mathrm{H}_{2}$ Salen Ligand and [Mn(salen)OAc] Complex}

Elemental analysis of the $\mathrm{H}_{2}$ salen $\left(\mathrm{C}_{16} \mathrm{H}_{16} \mathrm{~N}_{2} \mathrm{O}_{2}\right)$ and [Mn(salen)OAc] complex compound $\left(\mathrm{MnC}_{18} \mathrm{H}_{17} \mathrm{~N}_{2} \mathrm{O}_{4}\right)$ resulted from synthesis show that each compound has $\mathrm{C}, \mathrm{H}$, and $\mathrm{N}$ elements percentage which fit the theoretical calculations (Table 1). These results indicate that $\mathrm{H}_{2}$ salen and [Mn(salen)OAc] complex compound have been successfully synthesized. 
Table 1. Elemental analysis of $\mathrm{C}, \mathrm{H}$, and $\mathrm{N}$ for $\mathrm{H}_{2}$ salen and [Mn(salen)OAc] complex

\begin{tabular}{|c|c|c|c|c|c|c|c|c|}
\hline \multirow[t]{2}{*}{ Compound } & \multirow[t]{2}{*}{$\begin{array}{l}\text { Empirical } \\
\text { Formula }\end{array}$} & \multirow{2}{*}{$\begin{array}{l}\text { Relative } \\
\text { Molecular } \\
\text { Mass }\end{array}$} & \multicolumn{3}{|c|}{$\begin{array}{c}\text { Calculation } \\
(\%)\end{array}$} & \multicolumn{3}{|c|}{$\begin{array}{c}\text { Found } \\
(\%)\end{array}$} \\
\hline & & & $\mathbf{C}$ & $\mathbf{H}$ & $\mathbf{N}$ & $\mathbf{C}$ & $\mathbf{H}$ & $\mathbf{N}$ \\
\hline $\mathrm{H}_{2} \mathrm{Sal}$ & $\mathrm{C}_{16} \mathrm{H}_{16}$ & 268.31 & 71.62 & 6.01 & 10.44 & 71.60 & 6.05 & 10.44 \\
\hline [Mn(salen)OAc] & $\mathrm{MnC}_{18} \mathrm{H}_{17} \mathrm{~N}_{2} \mathrm{O}_{4}$ & 380.28 & 56.85 & 4.51 & 7.52 & 56.69 & 4.21 & 7.52 \\
\hline
\end{tabular}

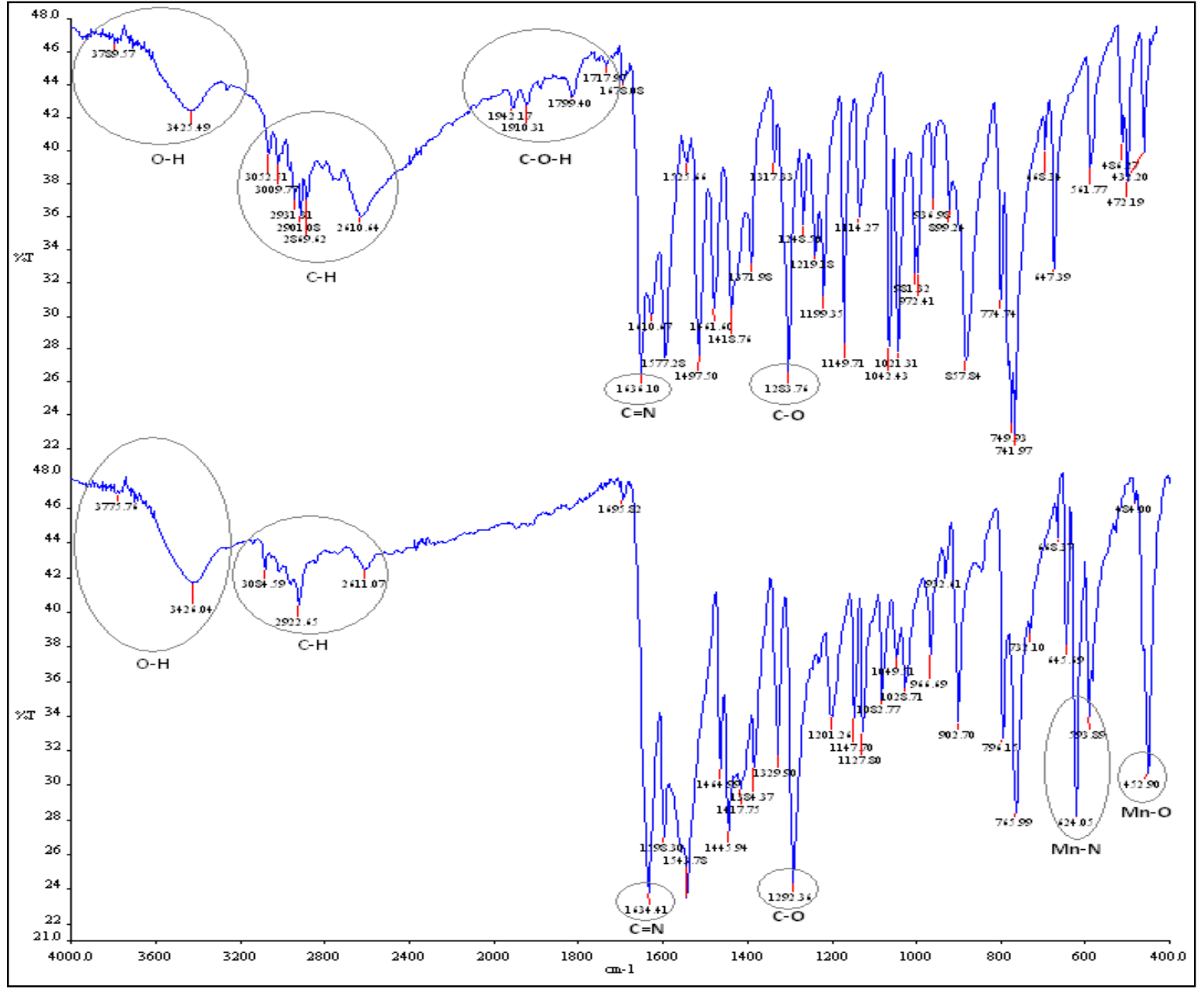

Figure 1. Infrared spectra of: $\mathrm{H}_{2}$ salen (above), [Mn(salen)OAc] (bottom)

In the infrared spectrum of the [Mn(salen)OAc] complex (Figure 1 (below)), several different wave numbers are observed compared with the $\mathrm{H}_{2}$ salen spectrum (Figure 1 (above)). The differences are observed in the vibration of $\mathrm{O}-\mathrm{H}, \mathrm{C}-\mathrm{H}, \mathrm{C}-\mathrm{O}-\mathrm{H}, \mathrm{Mn}-\mathrm{N}$, and $\mathrm{Mn}-\mathrm{O}$ functional groups. In the complex compounds, the vibration of $\mathrm{O}-\mathrm{H}$ and $\mathrm{C}-\mathrm{H}$ functional groups occurs successively in the wave numbers of 3426-3775 and 2611-3084 $\mathrm{cm}^{-1}$, while the ligands occurred successively in the wave numbers of 3425-3789 and 26103052. The vibration of C-O-H which appeared at the wave numbers of $1717-1942 \mathrm{~cm}^{-1}$ in the $\mathrm{H}_{2}$ salen spectrum, did not appear in the spectrum of [Mn(salen)OAc] complex. This fact indicates that after $\mathrm{H}_{2}$ salen bound to $\mathrm{Mn}(\mathrm{III})$, the vibration of $\mathrm{C}-\mathrm{O}-\mathrm{H}$ did not happen again due to the release of the $\mathrm{H}$ atom of the -OH group of $\mathrm{H}_{2}$ salen. Metal-ligand bond in the [Mn(salen)OAc] complex can be observed in the fingerprint region at the wave number of 593-624 $\mathrm{cm}^{-1}(\mathrm{Mn}-\mathrm{N})$ and $452 \mathrm{~cm}^{-1}$ (Mn-O).

Measurement of the ESI-MS mass spectrometry of [Mn(salen)OAc] complex was carried out in methanol-acetonitrile. In the positive ionization spectrum (Figure 2 (left)), a cationic species with a high-intensity peak was observed at $\mathrm{m} / \mathrm{z} 320.9$ which corresponding to the four-coordinated cation $[\mathrm{Mn}(\text { salen })]^{+}$. This suggests that the 
$[\mathrm{Mn}(\text { salen })]^{+}$cation is the parent species of the [Mn(salen)OAc] complex compound. Besides, a moderate intensity peak also observed at $\mathrm{m} / \mathrm{z} 269.0$, which corresponding to a cationic free ligand species $(\text { salen }+\mathrm{H})^{+}$. On the other side, in the negative ionization spectrum (Figure 2 (right)), a peak indicating two acetate ions which coordinated to the $\mathrm{Mn}(\mathrm{III})$ ion was observed, although the intensity was very low, that is at $\mathrm{m} / \mathrm{z} 441$, corresponding to the anion species of $\left[\mathrm{Mn}(\mathrm{salen})(\mathrm{OAc})_{2}\right]^{-}$. In addition, the negative ionization spectrum is also observed three peaks at $\mathrm{m} / \mathrm{z}$ 255.0, 265.0, and 283.1, which corresponding to the $(\text { salen }-\mathrm{N})^{-}$, (salen - H) and $(\text { salen }+\mathrm{N})^{-}$. Meanwhile, a peak at $\mathrm{m} / \mathrm{z}$ 319 which corresponding to the [Mn (salen) $\mathrm{H}){ }^{-}$species showed that the acetate ion binding to the $\mathrm{Mn}$ (III) ion could be broken). Based on the results of the ESI-MS, the [Mn(salen)OAc] complex compound have been successfully synthesized.

The conductometry measurement results of the [Mn(salen)OAc] complex compound can be seen in Table 2. The methanolic solution of the complex was provided a molar conductivity of $0.17 \mathrm{mS}$. This molar conductivity is smaller than the value of the smallest molar conductivity of $\mathrm{NaCl}$ ionic compound. These results indicate that the complex is a neutral [Mn(salen)OAc] complex compound, where the acetate bound as ligands to $\mathrm{Mn}$ (III) or in other words it is not as a free anion or a counter ion. The results obtained from this molar conductivity value measurements in accordance with the molecular formula of the ionic species that appear on the ESI-MS spectrum and the content of $\mathrm{C}, \mathrm{H}, \mathrm{N}$ on elemental analysis.

Based on the result of magnetic measurement, the [Mn(salen)OAc] complex compound is paramagnetic with the experimental magnetic susceptibility of 4.93 $\mathrm{BM}$. This value indicates that the solution reaction of $\mathrm{Mn}(\mathrm{II})$ with $\mathrm{H}_{2}$ salen caused oxidation of $\mathrm{Mn}$ (II) to $\mathrm{Mn}$ (III) ion. This result are consistent with the theoretical magnetic susceptibility of $\mathrm{Mn}^{3+}$, which has four unpaired electrons $\left(\mu_{\text {theory }}=4.90 \mathrm{BM}\right)$.
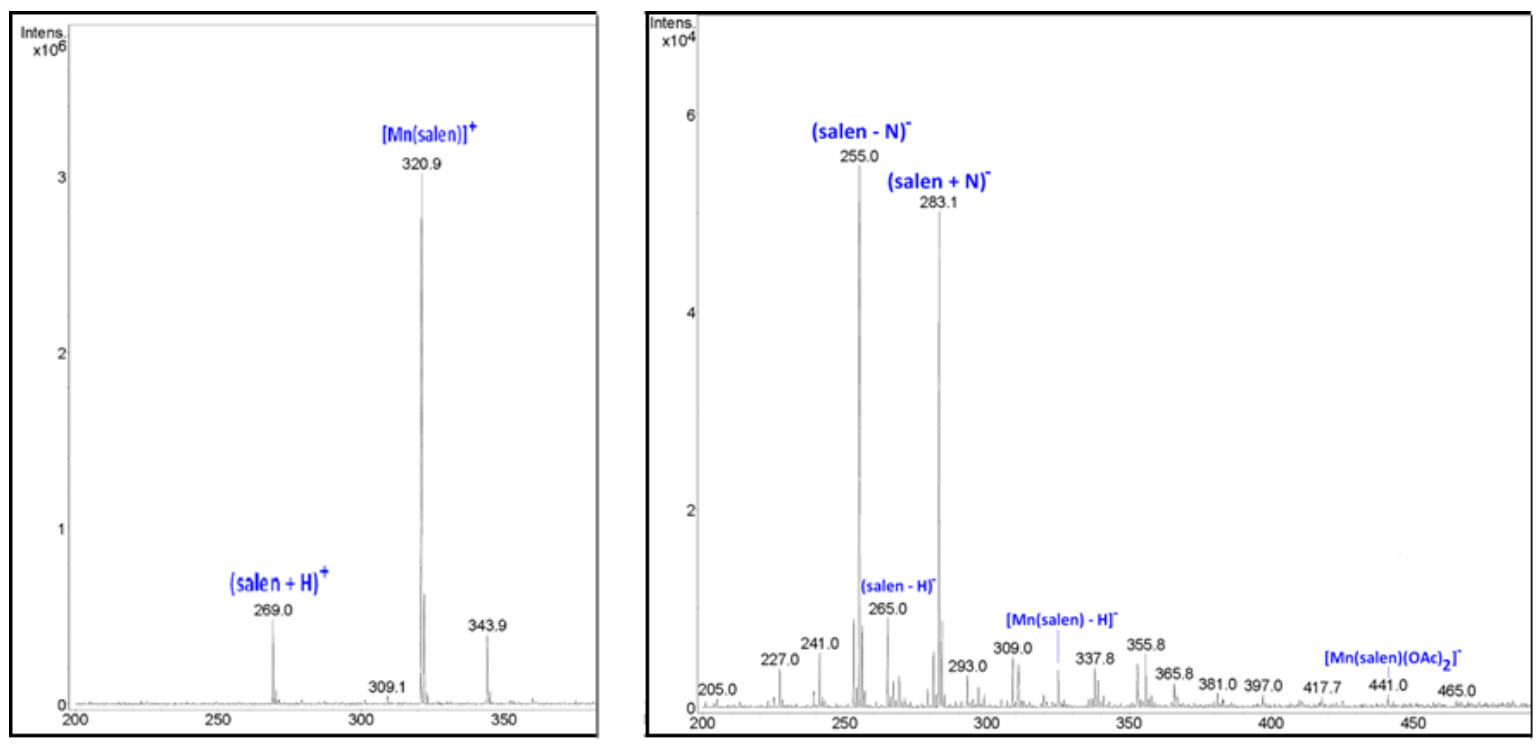

Figure 2. The ESI-MS spectrum of [Mn(salen)OAc] complex compound in a solution of methanolacetonitrile for: positive ionization region (left) and negative ionization region (right)

Table 2. The results of the molar conductivity measurements

\begin{tabular}{lccc}
\hline \multicolumn{1}{c}{ Solution } & Solvent & $\begin{array}{c}\boldsymbol{\Lambda} \\
(\mathbf{m S})\end{array}$ & Number of ions \\
\hline Methanol & - & 0 & - \\
$\mathrm{H}_{2}$ Salen & - & 0 & - \\
$\mathrm{NaCl}$ & Methanol & 0.21 & 2 \\
$\mathrm{Mn}(\mathrm{OAc})_{2} \cdot 4 \mathrm{H}_{2} \mathrm{O}$ & Methanol & 0.33 & 3 \\
{$[\mathrm{Mn}(\mathrm{salen}) \mathrm{OAc}]$} & Methanol & 0.17 & - \\
\hline
\end{tabular}




\section{Activity of SOD of [Mn(salen)OAc] Complex Compound}

The potential as mSOD of the [Mn(salen)OAc] complex compound was determined by $\mathrm{IC}_{50}$ value, that is the concentration of the complex which is able to inhibit the reduction of NBT by superoxide anion as well as $50 \%$. The SOD activity was tested in vitro non-enzymatically through riboflavin photoreduction and NBT is used as an indicator that can be reduced to NBTdiformazan when it reacts with superoxide anions generated from photoreduction of riboflavin. This indirect method includes several reactions: the photochemically excited riboflavin was first reduced by TEMED into semiquinone, which donated an electron to oxygen to form superoxide anion source. The superoxide readily converted a yellow NBT into a purple formazan product. The SOD activity was inversely related to the amount of formazan formed

The measurement results of the inhibition of the [Mn(salen)OAc] complex against NBT reaction with superoxide in the form of absorption values before and after irradiation are shown in Table 3. An empty microplate before being filled by any mixture gives the same absorption, about 0,060 , either before or after lighting.

Table 3. The absorbance data of SOD activity test of [Mn(salen)OAc] complex

\begin{tabular}{|c|c|c|c|c|c|}
\hline \multirow{2}{*}{$\mathrm{N}_{0}$} & \multirow{2}{*}[\mathrm{Mln}(\mathrm{alalen})0\mathrm{Acc}]{} & \multirow{2}{*}{$\begin{array}{l}\text { No. of } \\
\text { Data }\end{array}$} & \multicolumn{2}{|c|}{$A_{\text {sample }}$} & Inlibition (08) \\
\hline & & & & II & I III \\
\hline Standerd & 0 & - & 0,755 & 0,788 & 0 \\
\hline \multirow[t]{5}{*}{1} & $0.5 \mu \mathrm{II}$ & 1 & 0.758 & 0.796 & $\begin{array}{lll}0 & .1 & 3.4\end{array}$ \\
\hline & & 2 & 0.721 & 0.755 & 55 \\
\hline & & 3 & 0.739 & 0.774 & 22 \\
\hline & & 4 & 0.77 & 0.733 & .28 \\
\hline & & Rate & & & 2 \\
\hline \multirow[t]{5}{*}{2} & $1 \mu \mathrm{II}$ & 1 & 0.593 & 0.685 & $24 \quad 14 \quad 3.0$ \\
\hline & & 2 & 0.608 & 0.655 & $21 \quad 18$ \\
\hline & & 3 & 0.592 & 0.64 & $24 \quad 20$ \\
\hline & & 4 & 0.623 & 0.647 & $19 \quad 20$ \\
\hline & & Rate & & & 20 \\
\hline \multirow[t]{5}{*}{3} & $1.5 \mu \mathrm{MI}$ & 1 & 0.528 & 0.564 & $\begin{array}{llll}33 & 31 & 2.7\end{array}$ \\
\hline & & 2 & 0.555 & 0.572 & $29 \quad 30$ \\
\hline & & 3 & 0.528 & 0.524 & $33 \quad 37$ \\
\hline & & 4 & 0.556 & 0.542 & $29 \quad 34$ \\
\hline & & Rate & & & 32 \\
\hline \multirow[t]{5}{*}{4} & $2 \mu \mathrm{UI}$ & 1 & 0.507 & 0.518 & $\begin{array}{lll}36 & 37 & 2.4\end{array}$ \\
\hline & & 2 & 0.484 & 0.516 & $39 \quad 38$ \\
\hline & & 3 & 0.479 & 0.487 & $40 \quad 42$ \\
\hline & & 4 & 0.478 & 0.539 & $40 \quad 34$ \\
\hline & & Rate & & & 38 \\
\hline
\end{tabular}

\begin{tabular}{|c|c|c|c|c|c|}
\hline \multicolumn{3}{|c|}{$v_{0}$ Min(salen) OAc No of } & \multicolumn{3}{|c|}{$A_{\text {sample }} \quad$ Inlibitition (06) } \\
\hline$N_{0}$ & & & I & $\mathrm{I}$ & $\frac{{ }_{I I}}{\mathrm{SD}}$ \\
\hline 5 & $3 \mu \mathrm{I} I$ & 1 & 0.3920 .409 & 53 & 530.8 \\
\hline & & 2 & 0.3850 .393 & 54 & 55 \\
\hline & & 3 & 0.3870 .395 & 53 & 54 \\
\hline
\end{tabular}

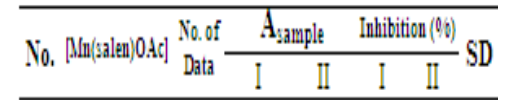

\begin{tabular}{ccccc} 
Notes: & & & & \\
\hline No, of & & $A_{\text {ztandard }}$ & \multicolumn{2}{c}{$A_{\text {blank } 1 \text { \&2 }}$} \\
\cline { 2 - 5 } Data & $I$ & $\mathbb{I}$ & $I$ & $\mathbb{I}$ \\
\hline 1 & 0.770 & 0.792 & 0.064 & 0.066 \\
2 & 0.727 & 0.792 & 0.062 & 0.067 \\
3 & 0.768 & 0.787 & 0.083 & 0.088 \\
4 & $\cdot$ & 0.779 & 0.078 & 0.072 \\
5 & $\cdot$ & - & 0.062 & 0.057 \\
6 & $\cdot$ & $\cdot$ & 0.055 & 0.06 \\
7 & $\cdot$ & - & 0.058 & 0.06 \\
\hline Rate & 0.755 & 0.788 & 0.066 & 0.067 \\
\hline & & & &
\end{tabular}

\begin{tabular}{|c|c|}
\hline OD Actiri & $y\left(I_{i 0}\right)$ \\
\hline of Dath & $\left.I C_{i 0}(\mu)\right]$ \\
\hline No, of Data & $\begin{array}{ll}\text { I II } \\
\text { II }\end{array}$ \\
\hline 1 & 2.82 .8 \\
\hline 2 & $\begin{array}{lll}2.7 & 27\end{array}$ \\
\hline 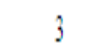 & $2.7 \quad 2.6$ \\
\hline 4 & $2.7 \quad 2.8$ \\
\hline Rate & 2.7 \\
\hline SD & 0.05 \\
\hline
\end{tabular}




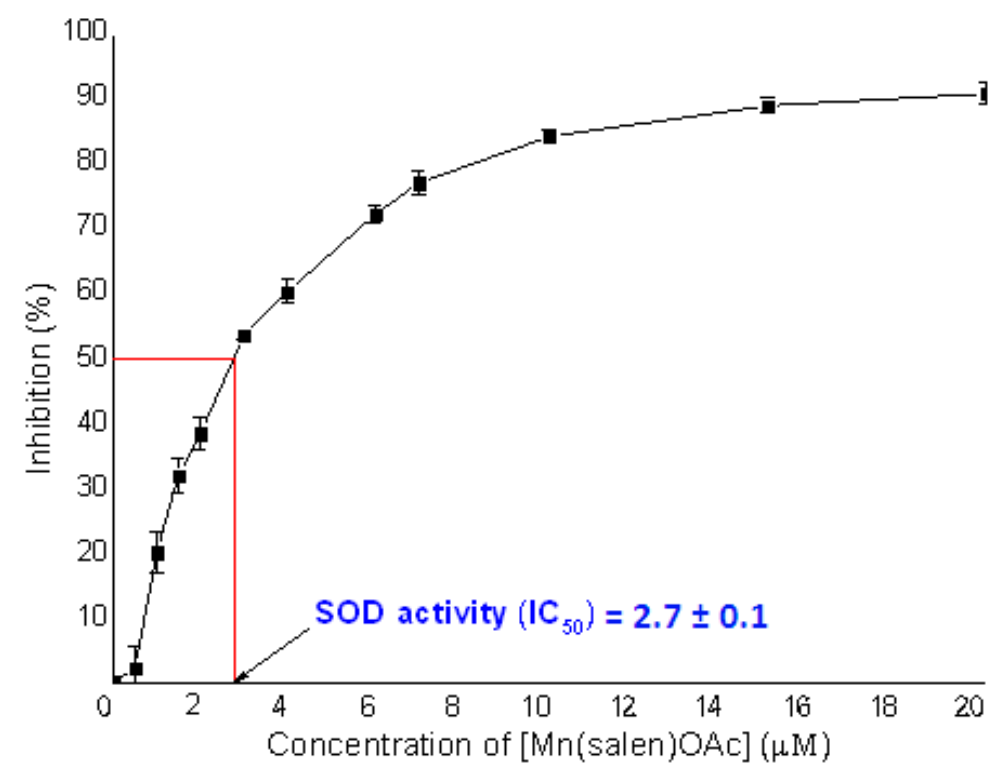

Figure 3. The curve of \%inhibition and various sample concentration solutions of [Mn(salen)OAc] complex

From the data of Table 3, some information are obtained, first, without lighting, no absorption of reduced NBT formazan that can be observed, which suggests that the superoxide anions were not formed so as not to react with NBT and there is no inhibition process. Similarly, what happened in the mixture without riboflavin (blanks 1 and blanks 2) after lighting. Second, the smaller the concentration of the complex compound in the solution (from left to right), the lower the inhibition ability of the complex against the NBT which indicated by the deeper of purple color of NBT formazan. Third, the absorptions of blanks 1 those are relatively common around 0,060 for all various concentration of sample beginning from deep brown to pale color from left to right, indicating that although colored, the [Mn(salenOAc] complex compound does not provide absorption at $\lambda 560 \mathrm{~nm}$.

The curve of \%inhibition and various sample concentration solutions of $[\mathrm{Mn}$ (salen)OAc] is shown in Figure 3. The extrapolation result of $50 \%$ inhibition was obtained from the complex compound with the concentration of $2.7 \pm 0.1 \mu \mathrm{M}$. Based on this result, the assay showed that the [Mn(salen)OAc] complex with the concentration of $2.7 \pm 0.1 \mu \mathrm{M}$ can inhibit as much as $50 \%$ of NBT works. The $\mathrm{IC}_{50}$ value obtained corresponds to the $\mathrm{IC}_{50}$ value in the previously reported study using the enzymatic method (Vecchio \& Lanza, 2009).

\section{CONCLUSIONS}

The activity of superoxide dismutase of the $[\mathrm{Mn}(\mathrm{salen}) \mathrm{OAc}]$ complex compound has been determined by in vitro non-enzymatic method through riboflavin photoreduction. Its potential as an SOD mimic was known from a high and accurate $\mathrm{IC}_{50}$ value of $2.7 \pm 0.1 \mu \mathrm{M}$ that obtained as well as $\mathrm{IC}_{50}$ obtained by the enzymatic method reported previously. Therefore, the in vitro non-enzymatic method of riboflavin photoreduction with NBT as an indicator can be used to determine the SOD activity of an SOD mimic of a metal complex compound by giving more stability and accuracy of $\mathrm{IC}_{50}$ value.

\section{ACKNOWLEDGEMENT}

This study was supported by The Scholarship of BPPDN 2013, The Scholarship of Sandwich-like Program (PKPI) 2015, and The PUPT Research Grants Batch II 2016 (No. 813g/11.C01/PL/2016) from The Directorate General of Higher Education, Republic of Indonesia. Then we would like to thank Prof. Dr. Evamarie Hey-Hawkins from The Institut für Anorganische Chemie, Fakultät für Chemie und Mineralogie, Universität Leipzig, Germany, for analysis of CHN elements, IR spectroscopy, and ESI-MS spectroscopy. And thank you to Dr. Debbie S. Retnoningrum from The Pharmaceutical Biotechnology Laboratory, School of Pharmacy, Institut Teknologi Bandung, for 
microplate reader spectrophotometer measurements.

\section{REFERENCES}

Barnese, K., Gralla, E. B., Cabelli, D. E., \& Valentine, J. S. (2008). The role of superoxide anion in the autoxidation of epinephrine and a simple assay for superoxide dismutase. Journal of the American Chemical Society, 130, 4604-4606.

Boucher, L. J., \& Farrell, M. O. (1973). Manganese schiff's base complexes-I: synthesis and spectroscopy of some anion complexes of (4-secbutylsalicyaldehydeethylenediiminato) manganese(III). Journal of Inorganic and Nuclear Chemistry, 35, 3731-3738.

Daier, V., Moreno, D., Duhayon, C., Tuchagues, J.-P., \& Signorella, S. (2010). Synthesis, characterization and combined superoxide dismutase and catalase activities of manganese complexes of 1,4bis(salicylidenamino)butan-2-ol.

European Journal of Inorganic Chemistry, 6, 965-974.

Doctrow, S., Huffman, K., Marcus, C. B., Tocco, G., Malfroy, E., Adinolfi, C. A., . . . Malfroy, B. (2002). Salenmanganese complexes as catalytic scavengers of hydrogen peroxide and cytoprotective agents. structure-activity relationship studies. Journal of Medicinal Chemistry, 45, 4549-4558.

Haberle, I. B., Reboucas, J. S., \& Spasojevic, I. (2010). Superoxide dismutase mimics: chemistry, pharmacology, and therapeutic potential. Antioxidants \& Redox Signaling, 6, 877-918.

Haikarainen, A., Sibila, J., Pietikainen, P., Pajunen, A., \& Mutikainen, I. (2001). Synthesis and characterization of bulky salen-type complexes of $\mathrm{Co}, \mathrm{Cu}, \mathrm{Fe}$, $\mathrm{Mn}$ and Ni with amphiphilic solubility properties. Journal of the Chemical Society, Dalton Transactions, 5, 991993.

Indrayati, A., Asyarie, S., Suciati, T., \& Retnoningrum, D. S. (2014). Study on the properties of purified recombinant superoxide dismutase from staphylococcus equorum, a local isolate from indonesia. International Journal of Pharmacy and Pharmaceutical Sciences, 6, 440-445.

Iranzo, O. (2011). Manganese complexes displaying superoxide dismutase activity: a balance between different factors. Bioorganic Chemistry, 39, 7387.

Janknegt, P. J., Rijstenbil, J. W., van de Poll, W. H., Gechev, T. S., \& Buma, A. G. J. (2007). A comparison of quantitative and qualitative superoxide dismutase assays for application to low temperature microalgae. Journal of Photochemistry and Photobiology B: Biology, 87, 218-226.

Kostyuk, V. A., Potapovich, A. I., Kostyuk, T. V., \& Cherian, M. G. (2007). Metal complexes of dietary flavonoids. evaluation of radical scavenger properties and protective activity against oxidative stress in vivo. Cellular and Molecular BiologyTM, 53, 61-68.

Li, X. (2012). Improved pyrogallol autoxidation method: a reliable and cheap superoxide-scavenging assay suitable for all antioxidants. Journal of Agricultural Food Chemistry, 60, 64186424.

Meftah, S., \& Yazdanparast. (2013). Synthesis and antioxidant activities of [5-fluoro n,n'-bis(salicylidene) ethylenediamine] and [3,5-fluoro n,n'-bis(salicylidene)ethylenediamine] manganese(III) complexes. Iranian Journal of Chemistry and Chemical Engineering, 32, 67-75.

Miriyala, S., Spasojevic, I., Tovmasyan, A., Salvemini, D., Vujaskovic, Z., St. Clair, D., \& Batinic-Haberle, I. (2012). Manganese superoxide dismutase, MnSOD and its mimics. Biochimica et Biophysica Acta, 1822, 794-814.

Moreno, D., Daier, V., Palopoli, C., Tuchagues, J.-P., \& Signorella, S. (2010). Synthesis, characterization and antioxidant activity of water soluble $\mathrm{Mn}^{\mathrm{III}}$ complexes of sulphonatosubstituted schiff base ligands. 2010, 104, 496-502.

Piacham, T., Isarankura-Na-Ayudhya, C., Nantasenamat, C., Yainoy, S., Ye, L., Bülow, L., \& Prachayasittikul, V. (2006). Metalloantibiotic Mn(II)bacitracin complex mimicking manganese superoxide dismutase. 
Biochemical and Biophysical Research Communications, 341, 925-930.

Retnoningrum, D. S., Rahayu, A. P., Mulyanti, D., Dita, A., Valerius, O., \& Ismaya, W. T. (2016). Unique characteristics of recombinant hybrid manganese superoxide dismutase from staphylococcus equorum and $S$. Saprophyticus. Protein Journal, 35, 136-144.
Vecchio, G., \& Lanza, V. (2009). Synthesis of superoxide dismutase (SOD) enzyme mimetics. A bioinorganic laboratory experiment. Journal of Chemical Education, 86, 1419-1421.

Yan, G., He, Y., Li, G., Xiong, Y., Song, P., \& Wang, R.-M. (2016). Bovine serum albumin metal complexes for mimic of SOD. Journal of Chemical Sciences, 128, 1783-1788. 